\title{
The outcome of pregnancy among Graves' women treated with PTU
}

\author{
Ali Imran Mukhsin*, Sarwono Waspadjï, Imam Subekti", Sidartawan Soegondo", Asman Boedisantoso \\ Ranakusuma ${ }^{\#}$, Slamet Suyono
}

\begin{abstract}
Abstrak
Hipertiroidisme yang tidak terkendali pada kehamilan dapat menyebabkan gangguan perkembangan dan pertumbuhan janin. Sebaliknya pengobatan yang berlebihan dapat mengakibatkan hipotiroidisme janin yang dapat menimbulkan kesulitan proses persalinan, gangguan pertumbuhan dan perkembangan intelektual bayi yang dilahirkan. Namun jika hipertiroidisme terkendali, kehamilan dan persalinan akan berlangsung normal. Telah dilakukan penelitian untuk mengetahui pengaruh pengendalian hipertiroidisme dengan PTU pada ibu hamil terhadap fungsi tiroid bayi yang dilahirkan. Dosis PTU disesuaikan dengan kadar $T_{4} /$ $F T_{4}$ dan TSH ibu yang diperiksa setiap bulan dari mulai kehamilan sampai melahirkan. Kadar TSH bayi dievaluasi dari tali pusar dan pada saat persalinan juga dievaluasi kadar TRab ibu melalui darah vena. Semua bayi (12 bayi) dilahirkan dalam keadaan normal tanpa kelainan bawaan, di antarany'a ada yang dilahirkan dengan bedah sesar atas indikasi ginekologi. Rerata berat lahir, denyut jantung , TSH dan kadar TRab berturut-1uit adalah $3053 \pm 279$ gram, $134,5 \pm 8,4$ kali permenit, $6,4 \pm 6,7 \mu \mathrm{g} / \mathrm{dL}$ dan $18,7 \%$ sedangkan rerata dosis total PTU (a $50 \mathrm{mg}$ pertablet) selama kehamilan adalah 200-300 tablet. Terdapat korelasi yang bermakna aniara skor dosis PTU selama hamil dengan kadar TSH bayi, namun tidak ada korelasi antara TSH bayi dengan kadar TRab ibu saat melahirkan. Disimpulkan penggunaan PTU selama kehamilan dengan hipertiroidisme aman bagi bayi yang dilahirkan bila dilakukan pemantauan yang ketat terhadap fungsi tiroid ibu.
\end{abstract}

\begin{abstract}
Uncontrolled Graves' disease in pregnant women might result in abnormalities of the development and growth of the fetus. Once becoming euthyroid on antithyroid drug, the pregnancy might ensue toward term and normal delivery. Overtreatment however, might cause problems to the baby such as hypothyroidism and goitre, resulting in difficulties at the delivery and growth problems lditer in their life. Evaluation on the outcome of pregnancy and the delivered babies among pregnant Graves' women was conducted. All the pregnant Graves' mother attended our. Thyroid Clinic were treated with PTU. the dose were tailored according to the levels of $T_{4} /$ $F_{4}$ and TSH of the pregnant mother. Laboratory evaluation was done every month from the start of pregnancy up to the time of delivery, during which the fetus TSH from the umbilical cord blood and the mother's serum TRab were also measured. There were altogether 12 pregnant Graves' women completed their pregnancy during the year 1997. Some pregnancy ended with low SC due to gynecologic indication. All the babies born in this series were normal, without apparent congenital anomalies. The mean birthweight, heart'rate. TSH and TRab levels were $3053 \pm 279$ grams, $14.5 \pm 8.4$ beat/minute, $6.4 \pm 6.7 \mathrm{ug} / \mathrm{L}$ respectively. The mean serum TRab of the mother were $18.7 \%$. The average total dose of PTU during pregnancy was $200-300$ tablets of 50 mg. There was significant correiation between the amount of PTU tablets consumed during the pregnancy and the levels of the umbilical cord blood THS level, but there was no correlation between the TRab and TSH levels of the born babies. It was concluded that the use of PTU among pregnant Graves' women, in conjunction with meticulous monitoring of pregnancy and thyroid function resulted in safe outcome of pregnancy.
\end{abstract}

Keywords: Pregnancy, Graves' disease, PTU, mother's $T_{4}$, mother's TRab and babies TSH at delivery.

Important changes occur in thyroid physiologic features during pregnancy. The basal metabolic rate increases about 20\%. Estrogen stimulates the hepatic production of thyroid-binding globulin (TBG), the

- Division of Endocrinology and Metabolism, Faculty of Medicine, University of Indonesia, Jakarta, Indonesia

* Department of Medicine, Faculty of Medicine, University of Indonesia. Jakarta. Indonesia primary transport protein for thyroid hormone. TBG serum concentration doubles early in pregnancy. Because TBG binds more thyroxin and triiodothyronin than normal, total serum triiodothyronin and thyroxin concentration nearly double, rising well above normal. However, free (unbound) serum thyroid hormone concentrations fall because of increased binding but remain within the normal range. The thyroid gland becomes overactive, showing histologic features of stimulation, and radioiodine uptake 
increases. However, during this time, serum TSH declines to the lower limits of normal. ${ }^{1}$

The prevalence of hyperthyroidism in pregnant women has been reported to be in the range of 0.05 $0.2 \%$. In 9,453 early pregnant women residing in Japan $0.4 \%$ had hyperthyroidism (mainly with untreated Graves' disease). ${ }^{2}$

Mild to moderately thyrotoxic women remains ovulatory and is not necessarily to be infertile. Infants of poorly controlled hyperthyroid mothers are at risk of prematurity, intrauterine growth retardation, and neonatal morbidity, such as fetal or neonatal hyperthyroidism due to transplacental passage of TRAB (TSH receptor antibody). On the other hand, overtreatment may cause neonatal hypothyroidism. ${ }^{3}$

The management of Graves' disease during pregnancy has been studied intensively. The therapeutic goals were to maintain the mother in a pregnant euthyroid or slightly hyperthyroid state and to keep the fetus in a euthyroid state. Thyroid dysfunction and goitre are sometimes found in neonates born to mothers with autoimmune thyroid disease, due to maternal TSHreceptor antibody and antithyroid drugs, both of which are readily transferred across the placenta. ${ }^{3-5}$

This study was carried out to see the effect of using prophylthiouracil in controlling maternal hyperthyroidism to the new borns/infants' thyroid function status.

\section{MATERIALS AND METHODS}

This cross sectional study was performed at Division of Endocrinology and Metabolism, Department of Medicine, University of Indonesia / Dr. Cipto Mangunkusumo hospital during the year 1997.

\section{Subjects}

Twelve neonates born in 1997 were consecutively studied. They were born to 12 women with hyperthyroidism treated with prophylthiouracil during gestation period. The treatment follow up for their Graves' disease was done at the Division of Endocrinology and Metabolism, Department of Medicine University of Indonesia.

\section{Laboratory studies}

Serum thyroxin levels $\left(\mathrm{T}_{4}\right)$ and TSH were assayed from the mothers using radioimmunoassay with a commercial kit (Amerlex- $\mathrm{M} \mathrm{T}_{4}$ RIA kits) at the first visit and $T_{4}$ was subsequently measured every 4 week. TSH receptor antibody (TRAB) level was measured by Radio Receptor Assay (RRA) with Kit Bio International at the time of delivery.

Neonatal umbilical cord's blood TSH was assessed at delivery.

Antithyroid drug (propylthiouracil-PTU) was given to all the patients, to maintain the serum thyroid hormone level at the mean $\mathrm{T}_{4} \sim 15 \mathrm{ug} / \mathrm{dL}$, the total $\mathrm{T}_{4}$ levels of normal pregnancy without any thyroid problems in our previous study. The total amount of PTU administered was calculated using the score of PTU dose expressed as :

Score 0 : PTU was given less than 100 tablets (50 mg/tablet).

Score 1 : PTU was given between 101-200 tablets.

Score 2: PTU was given between 201-300 tablets.

Score 3 : PTU was given between 301-400 tablets.

Score 4: PTU was given between 401-500 tablets.

Score 5 : PTU was given above 500 tablets.

\section{Data processing}

The collected data were included in the case record form, tabulated according to the aims of the study. There after they were edited, coded, and stored in the hard disk using IBM compatible personal computer with the help of software SPSS for window release 6.0 and presented in table and graphic form.

Multivariate analysis was performed to find out the correlation between fetal TSH and PTU total dose, as well as mother's TSH receptor antibody at delivery.

\section{RESULT}

Table 1 lists the characteristics of the 12 subjects (mothers and neonates) included in this study.

Table 2 lists the clinical features of the subjects (maternal hyperthyroidism) at the commencement of the study. Hyperhidrosis/excessive sweating was found in all of the patients, and $83 \%$ of patients had tremulous hand. 
Table 1. Characteristics of the Subjects

\begin{tabular}{lcc}
\hline Haemoglobine & $12.6 \pm 0.8 \mathrm{~g} / \mathrm{dL}$ \\
Albumin & $4.3 \pm 0.4 \mathrm{mg} / \mathrm{dL}$ \\
Median dose PTU (score) & 2.5 & \\
Median TRAB & $18.7 \%$ & \\
Matemal T 4 during pregnancy & $14.4 \pm 4.1 \mu \mathrm{g} / \mathrm{dL}$ \\
Neonatal TSH & $6.4 \pm 6.7 \mu \mathrm{IU} / \mathrm{mL}$ \\
Birth weight & $3050 \pm 279.1 \mathrm{~g}$ \\
Heart beats & $134.5 \pm 8.4 \mathrm{beat} / \mathrm{min}$ \\
\hline
\end{tabular}

Table 2. Clinical Features of Maternal Hyperthyroidism

\begin{tabular}{lcc}
\hline \multicolumn{1}{c}{$\begin{array}{c}\text { Symptoms and } \\
\text { Signs present }\end{array}$} & $\begin{array}{c}\text { Uncontrolled } \\
(\%)\end{array}$ & $\begin{array}{c}\text { Controlled } \\
(\%)\end{array}$ \\
\hline Palpitation & 75 & 0 \\
Tremor & 83.3 & 16.7 \\
Irritable & 58.3 & 8.3 \\
Hyperhidrosis/excessive & 100 & 16.7 \\
$\quad$ sweating & & \\
Weakness & 66 & 0 \\
Exophthalmos & 83.3 & 83.3 \\
\hline
\end{tabular}

Table 3 shows several parameters of thyroid function at delivery of the neonates (umbilical cord blood) and their mother's (TRAB) as well as data on PTU administered to the mothers (total dose, dose score, mean daily dose, duration of administration, and time i.e. months of gestation during which PTU withdrew). The lowest total dose of PTU was 60 tablets $(50 \mathrm{mg} /$ tablet $)$ and the highest was 1305 tablets. The lowest daily dose of PTU was $50 \mathrm{mg}$ and the highest was $300 \mathrm{mg}$. The longest administration of PTU was 240 days and the shortest was 14 days.

The neonatal TSH levels less than $20 \mathrm{uIU} / \mathrm{ml}$ (normal $<20 \mathrm{uIU} / \mathrm{mL}$ ) were found in $11(91.7 \%)$ neonates, one $(8.3 \%)$ neonate have TSH levels more than 20 $\mathrm{uIU} / \mathrm{mL}$.

Fetal heart beat and respiratory rate was found within normal limit, ranged from the lowest 120 beat per minute to the highest 148 beat per minute. All the neonates had normal Apgar Score.

The lowest mother's TRAB levels at delivery were $1 \%$ and the highest was $57 \%$. Mother's TRAB levels at delivery of less than $15 \%$ were found in $5(41.7 \%)$ patients and $6(50 \%)$ patients had TRAB levels of more than $15 \%$, but 1 patient $(8.3 \%)$ did not have TRAB data.

Table 3. Total dose (TD), dose score (SD) mean daily dose MDD), duration of administration (D), month of gestation at which PTU was withdrawn (withd), mother's TRAB and TSH as measured in umbilical cord's blood.

\begin{tabular}{|c|c|c|c|c|c|c|c|}
\hline \multirow[t]{2}{*}{ NO } & \multicolumn{5}{|c|}{ PTU } & \multirow{2}{*}{$\begin{array}{c}\text { Neonat } \\
\text { TSH } \\
\text { UIU/mL }\end{array}$} & \multirow{2}{*}{$\begin{array}{l}\text { Mother } \\
\text { TRAB } \\
(\%)\end{array}$} \\
\hline & $\begin{array}{c}\text { TD } \\
\text { (tablets) }\end{array}$ & SD & $\begin{array}{l}\text { MDD } \\
(\mathrm{mg})\end{array}$ & $\begin{array}{c}\mathrm{D} \\
\text { (days) }\end{array}$ & $\begin{array}{c}\text { Withd } \\
\text { (month) }\end{array}$ & & \\
\hline 1 & 160 & 1 & 50 & 160 & 2 & 5.9 & 28 \\
\hline 2 & 80 & 0 & 300 & 14 & 9 & 2.4 & 38 \\
\hline 3 & 600 & 5 & 150 & 180 & $\#$ & 24 & 9.1 \\
\hline 4 & 1305 & 5 & 200 & 240 & \#\# & 12.8 & 12.7 \\
\hline 5 & 133 & 1 & 100 & 66 & 6 & 0.4 & 37.8 \\
\hline 6 & 90 & 0 & 100 & 45 & 3 & 3.5 & 30 \\
\hline 7 & 60 & 0 & 100 & 30 & 2 & 2.7 & 12.2 \\
\hline 8 & 144 & 1 & 100 & 72 & 7 & 5.3 & 1 \\
\hline 9 & 1100 & 5 & 275 & 200 & 8 & 4.9 & 18.7 \\
\hline 10 & 410 & 4 & 200 & 102 & 8 & 5.9 & 1 \\
\hline 11 & 240 & 2 & 200 & 60 & 9 & 2.2 & 57 \\
\hline 12 & 480 & 4 & 175 & 137 & 9 & 3.56 & $\mathrm{Nd}$ \\
\hline
\end{tabular}

\# PTU was given at the first 5 months, stopped and then readministered on the last month of pregnancy

\# PTU was given at the first 7 months, then stopped and readministered in the last month of pregnancy

nd : no data available

Table 4 shows the features of PTU's dose score, number of patient and neonates TSH levels. There was a significant correlation between PTU dose score and neonates TSH levels $(\mathrm{r}=0.668, \mathrm{p}=0.024)$ as depicted in figure 1.

Table 4. The Features of PTU's Score Dose, Number of Patient and Neonates TSH Levels

\begin{tabular}{ccc}
\hline PTU dose score & N & Mean Neonates 'TSH \\
\hline 0 & 3 & 2.9 \\
1 & 3 & 3.9 \\
2 & 1 & 2.2 \\
3 & 0 & - \\
4 & 2 & 4.7 \\
5 & 3 & 13.9 \\
\hline
\end{tabular}




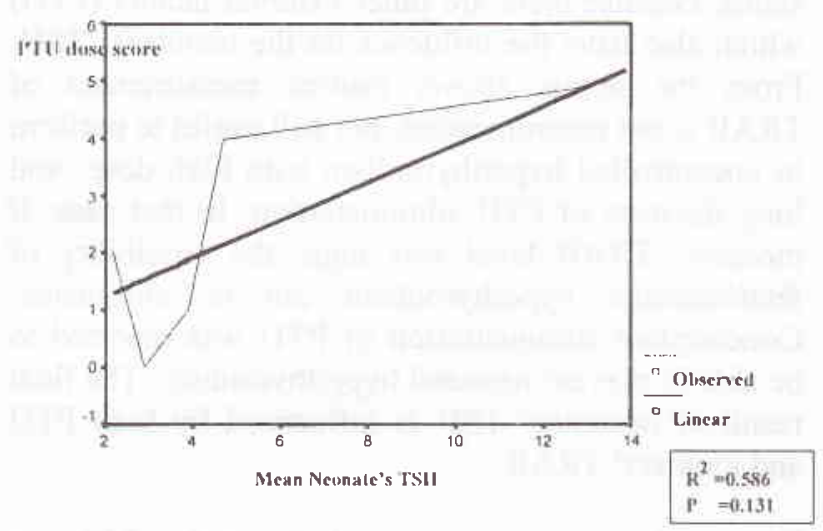

Figure 1. Relationship Between PTU dose score and Mean Neonates' TSH

Mother's TRAB at delivery could influence neonates' TSH levels. The higher mother's TRAB levels the lower the neonates' TSH levels are (table 5).

Table 5. Mother's TRAB at Delivery, and Neonates' TSH Levels

\begin{tabular}{ccc}
\hline Mother's TRAB & N & Neonates' TSH \\
\hline$<15$ & 5 & 10.4 \\
$>15$ & 6 & 3.2 \\
\hline
\end{tabular}

There was no significant correlation between mother's TRAB at delivery with neonates' TSH. (Pearson correlation $r=-0.464, p=0.150$, figure 2 ).

The mothers' $T_{4}$ levels during pregnancy and the PTU administration duration seem to have an effect on the neonates' TSH levels. The higher the mothers' $T_{4}$ levels and the longer the PTU administration tended to increase the neonates' TSH levels. There was significant correlation between the mothers' $T_{4}$ levels during pregnancy with neonates TSH levels $(r=$ 0.262 ).

The mean of mothers' $T_{4}$ levels during treatment in this study was $14.4 \pm 4.1 \mu \mathrm{g} / \mathrm{dL}$. During this study we tried to achieve the $T_{4}$ level $\sim 15 \mathrm{ug} / \mathrm{dL}$, since in our previous study, the average $T_{4}$ levels among normal pregnant women was $15 \mathrm{ug} / \mathrm{dL}$.

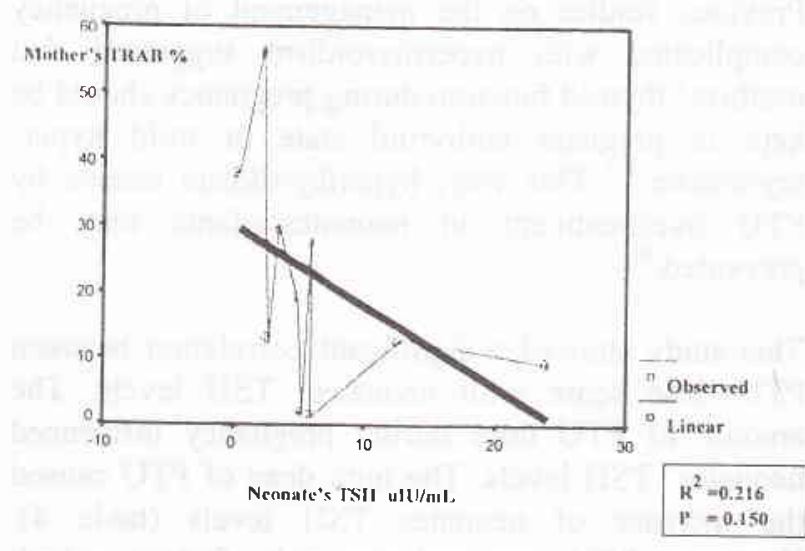

Figure 2. Relationship Between Mother's TRAB and Neonates' TSH

Table 6. The Mothers' $\mathrm{T}_{4}$, and Duration of PTU Administration

\begin{tabular}{cccc}
\hline $\begin{array}{c}\text { Mean } \\
\text { mothers' } \mathrm{T}_{4}\end{array}$ & $\begin{array}{c}\text { PTU } \\
\text { administered } \\
\text { duration (days) }\end{array}$ & $\mathrm{N}$ & $\begin{array}{c}\text { Mean } \\
\text { neonates TSH }\end{array}$ \\
\hline$<15$ & 89 & 7 & 4.7 \\
$>15$ & 136 & 5 & 8.1 \\
\hline
\end{tabular}

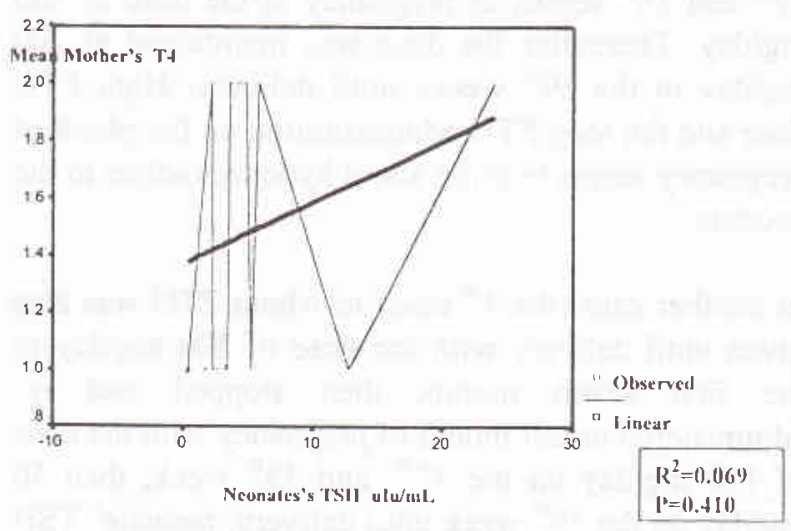

Figure 3. Relationship Between Mother's Mean $T_{4}$ During Pregnancy and Mean Neonatal TSH

Higher mothers' $T_{4}$ levels during pregnancy required longer duration of PTU administration and increased PTU dosage score, which eventually increased the neonates' TSH levels. 


\section{DISCUSSION}

Previous studies on the management of pregnancy complicated with hyperthyroidism suggested that mothers' thyroid function during pregnancy should be kept in pregnant euthyroid state or mild hyperthyroidism. ${ }^{4-7}$ This way, hyperthyroidism caused by PTU overtreatment in neonates/infants may be prevented. $^{8}$

This study showed a significant correlation between PTU dose score with neonates' TSH levels. The amount of PTU dose during pregnancy influenced neonates' TSH levels. The high dose of PTU caused the increase of neonates TSH levels (table 4). However, PTU was not the only factors, which influence neonates' TSH levels. Other factors which may influence neonates' TSH levels were mothers" TRAB. However, in this study we failed to demonstrate significant correlation between mothers' TRAB levels at delivery and neonates TSH.

In this study, from 12 examined patients, all except one neonates were born euthyroid clinically or laboratorically. In one case, the neonates was chemically hyperthyroid with TSH level of $24 \mu \mathrm{IU} / \mathrm{mL}$. The average mother's $T_{4}$ levels during pregnancy was 19.5 $\pm 3.2 \mu \mathrm{g} / \mathrm{dL}$. The patients got $150 \mathrm{mg} / \mathrm{day}$ of PTU at the first five month of pregnancy, than PTU administration was stopped and readministered on the $37^{\text {th }}$ and $38^{\text {th }}$ weeks of pregnancy at the dose of 300 $\mathrm{mg} /$ day. Thereafter the dose was maintained at 200 $\mathrm{mg} /$ day in the $39^{\text {th }}$ weeks until delivery. High PTU dose and the long PTU administration on the phase of pregnancy seems to bring about hypothyroidism to the neonate.

In another case (the $4^{\text {th }}$ case) to whom PTU was also given until delivery with the dose of $300 \mathrm{mg} /$ day in the first seven month, then stopped and readministered in last month of pregnancy with the dose of $100 \mathrm{mg} /$ day on the $37^{\text {th }}$ and $38^{\text {th }}$ week, then 50 $\mathrm{mg} /$ day on the $39^{\text {th }}$ week until delivery, neonate' TSH levels was still within normal limit. In this case, perhaps there was an effect of extra hypothalamic TRH and high TRAB levels.

In the $9^{\text {th }}$ case the total PTU dose was high $(1100$ tabs), the daily dose was also high $(275 \mathrm{mg})$, and the period of PTU administration was also long (200 days). But since the TRAB levels was high, the ensuing TSH level was not high. It seems that high mothers' TRAB at delivery (cases 1,2,5,6,9 and 11) did not determine the neonates' thyroid function status, because there are other external factors (PTU) which also have the influence on the neonates' TSH. From the points above, routine measurement of TRAB is not recommended, but still useful to perform in uncontrolled hyperthyroidism with high dose and long duration of PTU administration. In that case, if mothers' TRAB level was high, the possibility of fetal/neonatal hypothyroidism can be eliminated. Concomitant administration of PTU was reported to be able to prevent neonatal hyperthyroidism. The final result of neonates' TSH is influenced by both PTU and mothers' TRAB.

This result is in agreement with the study of Cheron RG et al $^{8}$ which reported an increase in neonates' TSH levels if PTU dose during pregnancy was more than $400 \mathrm{mg} /$ day. Based on that point, they performed further study intended to determine the PTU dose that avoid neonates hypothyroidism by giving maximum PTU dose of $300 \mathrm{mg} /$ day. It was reported that from 11 examined patients, all of them delivered euthyroid neonates except one case (neonatal TSH $>20$ $\mu \mathrm{IU} / \mathrm{ml}$ ), who had PTU in the first 8 months pregnancy of $100-150 \mathrm{mg} /$ day and $200 \mathrm{mg} /$ day in the last month of pregnancy. Refetoff et $\mathrm{al}^{8}$ reported the presence of neonatal goitre if PTU dose given to Graves' pregnancy mothers was more than 200 $\mathrm{mg} /$ day. Momotani et al ${ }^{9}$ reported that there was a correlation between PTU dose during pregnancy and neonates' TSH levels. Those studies indicated that beside the amount of PTU dose during pregnancy, there was also other factors influencing neonates' TSH level. Mitsuda et $\mathrm{al}^{4}$ proved that neonates' thyroid function is influenced by both total PTU dose during pregnancy and mothers' TRAB levels at delivery. This study yielded similar conclusion with other studies stated above.

In real clinical practice, the amount of PTU administered to the pregnant Graves' depends on the laboratory thyroid function with monthly monitoring throughout pregnancy period. To the uncontrolled mother, PTU was given in a laiger amount and a longer duration. However, considering that the total dose and duration of PTU administration influence neonates' TSH level, it is advocated that we have to be aware and careful in administering high dose and long duration of PTU in pregnant Graves' disease.

In this study, an increase in TSH level can be seen in neonates of mothers with average $\mathrm{T}_{4}$ levels $>15 \mu \mathrm{g} / \mathrm{dL}$ 
receiving longer PTU administration as compared to the mothers with average $\mathrm{T}_{4}$ levels $<15 \mu \mathrm{g} / \mathrm{dL}$. However, the neonates' TSH level of both groups were still within normal limits. On further analysis, however, there were significant correlation between mothers' $T_{4}$ levels during pregnancy with neonates' TSH levels. Similar result was also reported by Momotani et al. ${ }^{9}$

Neonates' TSH levels are not only influenced by PTU dose during pregnancy but also by TRAB level. Although there were no significant correlation between Mothers' TRAB with neonates' TSH in this study, there is a significant difference in neonates' TSH level in different Mothers' TRAB group at delivery (Wilcoxon Rank-Sum Test).

In this study PTU administration showed a positive linear correlation with neonates' TSH level, but on the other hand it showed a negative/reverse correlation with mothers' TRAB, especially when PTU administration was continued up to delivery. Our result is also similar to that obtained by Momotani et $\mathrm{al}^{9}$ and Matsuura et al. ${ }^{5}$ They found that PTU and TRAB influenced the neonates' thyroid function. Folley et al ${ }^{10}$ reported that TRAB level can be lowered by PTU administration and it was also proved in this study.

Tamaki et al ${ }^{11}$ investigated the correlation between neonates' thyroid dysfunction and neonates TSH (umbilical cord blood). They reported that low neonates' TSH levels and the presence of high TRAB could predict the occurrence of neonates' hyperthyroidism. Skuza et al ${ }^{12}$ reported that TRAB level of hyperthyroid patient with pregnancy will be normal if medication is given during pregnancy. TRAB levels are going to increase if medication was not given at all. Neonates' TSH level in the patients who had anti thyroid drugs was reported to be within normal limit. On the other hand neonates' TSH level of patients who did not receive any medication will be low, concordance with hyperthyroidism of the neonates. The result of this study is not different from the other studies mentioned above.

The mean birthweight found in this study was 3053 grams, ranged from 2500-3500 grams. This result is similar to the result reported by Mitsuda et $\mathrm{al}^{4}$ who reported mean birthweight of $3041 \pm 415$ grams. The lowest birthweight in this study was $2500 \mathrm{~g}$; the neonate was born to a patient with uncontrolled hyperthyroidism. Similar condition was reported by
Mitsuda et al who reported that patients with uncontrolled hyperthyroidism, treated or not, will give birth to neonates with lower birthweight compared to neonates of patients with controlled hyperthyroidism.

In this study, no congenital anomalies were found, although $3(25 \%)$ of the patients suffered from hyperthyroidism in early pregnancy. Neonatal congenital anomalies as reported by Momotani et al might occur if hyperthyroidism was uncontrolled at early pregnancy, while Wing et $\mathrm{al}^{13}$ did not find any congenital anomalies although hyperthyroidism occurred during embryogenesis at which patient was treated with antithyroid agent. Milham ${ }^{4}$ reported the occurrence of skin aplasia in a neonate born to a hyperthyroid mother who got methimazole therapy during pregnancy. Other studies however, dcubted the correlation between skin aplasia and Methimazole treatment since skin aplasia can also occur in patients with other thyroid dysfunction without methimazole treatment.

It is concluded that the control of hyperthyroidism during pregnancy will influence neonate thyroid function. The TSH level of neonate born to mothers with hyperthyroidism is positively correlated with PTU administration, while mothers' TRAB level at delivery is reversibly correlated with PTU administration. Optimal daily dose of PTU that was not resulted in neonate hypothyroidism is less than $300 \mathrm{mg}$. The PTU dose should be reduced to $100 \mathrm{mg} /$ day in the last four weeks before delivery if hyperthyroidism persists clinically and laboratorically.

Mean mothers' $\mathrm{T}_{4}$ level of $14.4 \pm 4 \mu \mathrm{g} / \mathrm{dL}$ during pregnancy did not cause any hypothyroidism in the neonates. Meticulous monitoring of pregnancy and the thyroid function resulted in safe outcome of pregnancy. Monthly surveillance is considered to be adequate.

The measure of the neonates' TSH level at birth is advocated to anticipate thyroid dysfunction in neonates born to hyperthyroid patients, as well as mothers' TRAB level in pregnancy if hyperthyroidism is uncontrolled by high dose and long period administration of PTU.

\section{REFERENCES}

1. Mazzaferri EL. Evaluation and management of common thyroid disorders in women. Am J Obstet Gynecol 1997; 507-14. 
2. Roti E, Minelli R, Salvi R. Management of hyperthyroidism and hypothyroidism in the pregnant woman. J Clin Endocrinol and Metab $1996 ; 81: 1679-82$.

3. Becks GP, Burrow GN. Thyroid disease and pregnancy. Med Clin North Am 1991; 75 : 121-50.

4. Mitsuda M, Tamaki H, Amino $\mathrm{N}$ et al. Risk factors for developmental disorders in infants born to women with Graves' disease. Obstet Gynecol 1992 ; 80 (3) : 359-64.

5. Matsuura N, Fujeda K, Iada $Y$, et al. TSH receptor antibodies in mothers with graves disease and outcome in their offspring. Lancet $1998 ; 1: 14-7$.

6. Supran $H$, Suyono $S$, Supartondo. Free $T_{4}, T_{3}$ uptake and Free Thyroxin Index of normal healthy women in Dr.Cipto Mangunkusumo Hospital. National Congress of the Indonesian Internal Medicine Society VI. Jakarta $1984 ; 1050-60$.

7. Mestman JG, Goodwin MM, Montoro MM. Thyroid disorders of pregnancy. Endocrinol Metab Clin North Am $1995 ; 24: 41-71$.

8. Cheron RG, Kaplan MM, Larsen PR, Selenkow HA, Crigler JF. Neonatal thyroid function after propylthiouracil therapy for maternal Graves' disease. N Engl. J Med $1981 ; 304$.
9. Momotani N, Noh J, Oyanagi H, Ishikawa N, Ito K. Antithyroid drugs therapy for Graves' disease during pregnancy. N Engl. J Med 1986 ; $315: 24-8$.

10. Foley TP, White C, New A. Juvenile Graves' disease : usefulness and limitations of thyrotropin receptor antibody determination. J Pediatric 1987 ; 110 : 378-86.

11. Tamaki H, Amino N, Takeoka K, et al. Prediction of later development of thyrotoxicosis or fetal hypothyroidism from the cord serum thyroid stimulating hormone level in neonates born to mothers with Graves disease, J Pediatric $1989 ; 115: 318-21$.

12. Skuza KA, Sills IN, Stene M, Rapaport R. Prediction of neonatal hyperthyroidism in infants born to mothers with Graves disease. J Pediatric 1996 ; 128 : 264-7.

13. Wing DA, Millar LK, Koonings PP, et al. A Comparison of propylthiouracil versus Methimazole in the treatment of hyperthyroidism in pregnancy. Am J Obstet Gynecol $1994 ; 170: 90-5$

14. Van Dijke CP, Heydendeael RJ, De Kleine MJ. Methimazole, Carbimazole, and congenital skin defects. Ann of Int. Med 1987; $106: 60-1$. 